УДК 378.22:378.013.2

DOI:

Любов Дольнікова, кандидат педагогічних наук, доцент кафедри педагогіки та соиіального управління Національний університет “Львівська політехніка" Олег Стечкевич, кандидат педагогічних наук, старший науковий співробітник, доцент кафедри педагогіки та соиіального управління Національний університет “Львівська політехніка”

\title{
ФОРМУВАННЯ ГОТОВНОСТІ МАЙБУТНІХ ДОКТОРІВ ФІЛОСОФІЇ ДО ІННОВАЦІЙНОЇ ПЕДАГОГІЧНОЇ ДІЯЛЬНОСТІ
}

У статті проведений аналіз теоретичних засад та практичних результатів формування готовності майбутніх докторів філософї до інновачійної педагогічної діяльності у закладі вищої освіти. Проаналізовано можливості формування готовності майбутніх докторів філософії до інновачійної педагогічної діяльності в процесі вивчення курсу “Професійна педагогіка". Запропоновано тематику практичних робіт для аспірантів першого року навчання, яка реалізує взаємодію учасників педагогічного процесу у формі випереджувального навчання через активну дискусію. Представлено результати спільної роботи на таких заняттях: основні риси педагога сучасної вищої школи, педагогічні умови підготовки до інноваційноі педагогічної діяльності, модель сучасного науково-педагогічного прачівника вищої школи.

Ключові слова: професійна педагогіка; інновачійна педагогічна діяльність; доктор філософії.

Jim. 8.

Lyubov Dolnikova, Ph.D.(Pedagogy), Associate Professor of the Pedagogy and Social Management Department

National University "Lviv Polytechnic"

Oleh Stechkevych, Ph.D.(Pedagogy), Senior Researcher, Associate Professor of the Pedagogy and Social Management Department National University "Lviv Polytechnic"

\section{CREATION OF READINESS FUTURE DOCTOR OF PHILOSOPHY FOR INNOVATIVE PEDAGOGICALACTIVITIES}

The article deals with an analysis of theoretical foundations and practical results of creation of readiness of future Doctors of Philisophy for the innovative pedagogical activities in the institution of higher education.

An important elementof training the Doctors of Philisophy is their readiness for the innovative professional scientific and pedagogical activities. Therefore, the modern training should be carried out by creative scientific and pedagogical workers who are ready to form the general and professional competences laid down in the standards on the basis of their own innovative approach, taking into account the demands of the labor market and the student's personality. The search for ways and means of restructuring the existing system of education and upbringing is ongoing. The problem of the modern system of education is not in individual disadvantages of textbooks or teaching methods, but in the content and activity components of the pedagogical process.

Innovative activity of the teacher of high school involves leaving from the conservative stamps as for the structure and organizational forms of education and the transition to the innovative methods of work. The important component of this activity is the development of creative personal abilities of the teachers as the basis for the formation of creative professional qualities.

The authors analyzed the possibilities of creation of readiness of future Doctors of Philisophy for innovative pedagogical activity during studying the course "Professional Pedagogy". The themes of practical work for postgraduate first-year students, which implements the interaction of participants in the pedagogical process in the form of forward learning through an active discussion, is proposed. The results of the joint work on such classes are presented including the main features of the teacher of modern high school, the pedagogical conditions of preparation for innovative pedagogical activity, a model of modern scientific and pedagogue of higher education.

Keywords: professional pedagogy; an innovative pedagogical activity; Doctor of Philisophy.

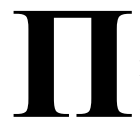

остановка проблеми. Аналіз проблем у сфері підготовки сучасного педагога засвідчує, що організацію цього процесу повинні здійснювати творчі науково-педагогічні працівники, які готові формувати закладені в стандартах загальні та фахові компетентності на основі власного інноваційного підходу з урахуванням запитів як ринку праці, так і особистості студента, який готується до успішної особистої професійної 

ДОІННОВАЦЙНОЇ ПЕДАГОГІЧНОЇ ДІЯЛЬНОСТІ

кар'єри. Досвід роботи сучасних науковопедагогічних працівників засвідчує, що лише $20 \%$ працюють над методикою запровадження інноваційних методик для отримання якісного кінцевого результату педагогічного процесу, а решта - працюють за класичним методом формування компетентностей студентів, не застосовуючи власних методик чи методик передових педагогів. Однак, вимоги Закону “Про освіту" і Закону України "Про вищу освіту" орієнтовані на запровадження інноваційних методик як в системі дошкільної, шкільної, професійно-технічної так і в закладах вищої освіти. Безперечно, це не можна зробити вже і сьогодні, але в системі підготовки докторів філософії важливим елементом $\epsilon$ їх готовність до інноваційної професійної та науково-педагогічної діяльності. Найважливішим, на наш погляд, $є$ переконання аспірантів в тому, що навчати "сьогодні так, як вчора", є переступом перед суспільством і перед студентом, тому обрана нами тема статті $є$ актуальною і потребує детального аналізу.

Мета дослідження - аналіз теоретичних засад та практичних результатів формування готовності майбутніх докторів філософії до інноваційної педагогічної діяльності у закладі вищої освіти.

Виклад основного матеріалу. Українське суспільство давно очікувало змін в освіті на законодавчому рівні, а в останнє десятиріччя питання навчання і виховання було чи не найбільш обговорюваним як науковцями, так і засобами масової інформації. Слід зазначити, що єдності у поглядах на очікувані зміни не було, але була одна спільна потреба у цих змінах, оскільки існуюча система освіти (як середньої, так і вищої) не відповідала запитам ні суспільства, ні ринку праці. Це розуміли практично всі, проте думки як вийти 3 цієї ситуації часом кардинально відрізнялись, причому найбільш консервативними залишались саме педагогічні та науково-педагогічні працівники, які не хотіли змін у змістовому та діяльнісному компонентах педагогічного процесу, нарікаючи на паперову бюрократію та низькі до приниження заробітні плати. В освіті наступила педагогічна революційна ситуація, коли суспільство чекає на результат освітньої діяльності - освічену і виховану особистість, а сама система освіти не в стані забезпечити цю потребу.

Ми вважаємо, що між суспільством i системою освіти має бути гармонійна взаємодія, а тоді цілі, зміст і завдання педагогічного процесу будуть реалізовані якісним кінцевим результатом, які закладено у державних, галузевих стандартах та стандартах закладу вищої освіти. Слід зазначити, що більшість критиків освітньої системи свою точку зору спрямовували на великий розрив між людиною, яка формально отримала диплом і вимогами суспільства, пояснюючи цей розрив саме недоліками освітньої системи, які часто зводились до тези, що студенти перевантажені інформацією, непотрібними предметами і даремно тратять час у ЗВО. У цьому контексті виникають дискусії про недоліки у виборі методів і засобів навчання, неефективності процесу навчання і роботи педагога, низькій мотивації студентів до навчання. Постало питання про необхідність змінити зміст освіти, враховуючи як запити особистості, так і запити ринку праці, який чекає на творчого, здатного до самоосвіти i самовдосконалення фахівця. Необхідно шукати шляхи і засоби перебудови існуючої системи навчання i виховання, обгрунтовувати i впроваджувати принципово нові підходи, що базуються на творчому науково-педагогічному працівникові, який знає і вміє забезпечити вимоги, поставлені перед ним державою і студентами.

На наш погляд, проблема сучасної системи освіти не в окремих недоліках підручників чи методиках навчання, а у змістовомуі діяльнісному компонентах педагогічного процесу, які повинні на інноваційному рівні зреалізувати цілі навчання, оскільки останні уже не можуть бути реалізовані традиційною системою навчання. Можемо переконливо зазначити, що тепер компетентності фахівця повинні мати біль абстрактну i узагальнену форму ніж раніше, а фахівець повинен бути як професійно, так і соціально мобільним. Ми вже готові до швидкоплинних змін у виробничій та інформаційній сферах, які зумовлюють динамічні переходи кадрів із однієі сфери в іншу, а часто, навіть і зміну спеціальності, а тому перед молодим фахівцем стає проблема перекваліфікації (перенавчання). Отже, людина повинна ще в закладі вищої освіти бути готовою до зміни професійної діяльності, тобто мати добру наукову і технічну освіту, яка забезпечить їй необхідну основу для певної групи професій і тоді процес переучування не буде таким стресовим i болючим. Молоді люди, що навчаються на освітньо-наукових програмах у переважній більшості бачать себе науковцями в тій чи іншій обраній ними спеціальності, але не виключають $і$ своєї педагогічної діяльності в майбутньому.

У курсі “Професійна педагогіка", який аспіранти вивчають на першому курсі, $є$ хороша нагода підготувати їх до інноваційної педагогічної 

ДОІННОВАЦЙНОӤ ПЕДАГОГІЧНОЇ ДІЯЛЬНОСТІ

роботи. В цьому контексті впровадження новацій та реалізація інноваційної діяльності є дуже актуальними i, на наш погляд, недостатньо вивченими саме в роботі з аспірантами. У педагогічній літературі нема єдності щодо трактування категорій інновація, новація, нововведення, інноватика тощо. Цікавими i такими, що обгрунтовують методологію проблеми є роботи С. Агапової [1], К. Ангеловскі [2], О. Бухнієвої [3], І. Гавриш [4], І. Гінсіровської [5], С. Кузьміна [6], А. Линенко, І. Піскарьової [7], Г. Подимової, О. Попової [8], А. Поручника та ін. Більшість авторів єдині в тому, що інновація це не просто нове, а впроваджене нововведення, яке призводить до вдосконалення існуючої системи.

Ми вважаємо, що інноваційна діяльність педагога вищої школи передбачає відмову від загальноприйнятого класичного підходу організування навчально-виховного процесу, відхід від консервативних штампів щодо структури і реалізації всіх організаційних форм навчання i перехід на інноваційні методики роботи 3 урахуванням місця дисципліни в структурнологічній схемі підготовки фахівців, попереднього навчального досвіду студентів, особистісних запитів, новітніх технологій у тій чи іншій галузі. При підготовці аспірантів до майбутньої педагогічної діяльності необхідно враховувати і потребу досягти успіху саме в педагогічній діяльності, розуміння власних цілей і оцінку їх важливості, почуття упевненості в якісному результаті, психологічну готовність до педагогічної роботи. Важливим компонентом $\epsilon$ також розвиток творчих здібностей самих педагогів як основа формування творчих фахових якостей.

У процесі вивчення курсу "Професійна педагогіка" для аспірантів першого року навчання в університеті ми пропонуємо не класичний, а посткласичний підхід до змістового наповнення лекційного матеріалу, що базується на активній взаємодії учасників педагогічного процесу у формі випереджувального навчання через активну дискусію на лекційних заняттях. Ця практика широко використовується у вищій європейській школі і має право та можливості бути зреалізованою українськими закладами вищої освіти. Розміщені у віртуальному навчальному середовищі лекції і розроблені до них запитання для дискусійного обговорення $є$ ефективним методом реалізації дидактичної і розвивальної мети лекції. Відхід від класичного монологу лектора і конспектування передбачає ефективне творче засвоєння матеріалу, долучає слухачів до активної роботи. Дуже часто під час таких лекцій- дискусій аспіранти діляться власними спостереженнями й інформацією, яку черпають 3 різних інформаційних джерел. Лектор стає не єдиним джерелом інформації, а модератором, який веде дискусію, формуючи живий пізнавальний інтерес і закладені в освітньонауковій програмі компетентності (як загальні, так і фахові). Таким чином, на основі численних класичних прийомів і методів формування знань, творчий педагог під час лекції формує нового творчого педагога, який має право працювати за своїми авторськими підходами.

Необхідно постійно ставити акцент на цій проблемі і тоді розробка нових методів і методик, потреба у їх впровадженні стане правилом для майбутнього науково-педагогічного працівника. Проте, тільки власного прикладу реалізації творчого підходу, на наш погляд, недостатньо. Обов'язковою умовою виступає ефективне залучення аспірантів до цієї роботи, формування їх готовності до педагогічної інноваційної діяльності. Це завдання реалізуємо під час формування тематики і методичного наповнення практичних робіт, які виконують надзвичайно важливу роль у підготовці аспірантів до інноваційної педагогічної діяльності. Нами розроблені практичні роботи, які уже за своєю тематикою викликають високий інтерес аспірантів до професійної педагогіки:

- аналіз нормативно-правового забезпечення освітньої діяльності в Україні;

- проблеми модернізації професійної освіти в Україні і за кордоном;

- наукові і науково-педагогічні дослідження: категоріальний апарат;

- особливості реалізації педагогічної комунікації, моделювання групової педагогічної взаємодії;

- зміст і завдання професійної освіти, складання елементів освітньо-професійної і освітньо-наукової програми;

- моделювання дидактичного проекту лекції, практичного, лабораторного заняття і складання рецензії на прослухану лекцію відповідно до вимог відділу забезпечення якості освіти НУ “Львівська політехніка";

- організування виховної роботи куратора академічної групи, обговорення тем превентивного виховання на різних курсах навчання;

- методика складання контрольних матеріалів для реалізації всіх форм і видів контролю у закладі вищої освіти.

3 досвіду зазначимо, що уже під час першої практичної роботи всі аспіранти дуже активно, критично обговорюють Закон України “Про вищу освіту” та Закон України "Про освіту”, зазначають 


\section{ФОРМУВАННЯ ГОТОВНОСТІ МАЙБУТНІХ ДОКТОРІВ ФІЛОСОФІЇ ДОІННОВАЦІЙНОӤПЕДАГОГІЧНОӤ ДІЯЛЬНОСТІ}

проблемні місця, “вносять” власні поправки і доповнення після опрацювання кожним аспірантом окремого розділу. Друга практична робота залучає аспірантів до ознайомлення і аналізу наукових розвідок у теоретичному та практичному підходах до питань модернізації вищої професійної освіти, залучає їх до активної науково-пошукової роботи, формує вміння аналізувати науково-педагогічну літературу, володіти науково-педагогічним стилем мовлення, відстоювати власну позицію щодо проблем в освіті і шляхів їх вирішення на державному рівні та на рівні окремого закладу вищої освіти чи науково-педагогічного працівника.

Чи не найбільший інтерес викликає в аспірантів можливість представити власні наукові інтереси, а відповіді на запитання представлених власних моделей педагогічної групової взаємодії підтверджують їх володіння проблемою та інформаційним взаємозбагаченням під час проведення елементів лекції, практичного, лабораторного чи семінарського заняття. Цікаву інформацію отримує викладач, коли аспіранти представляють рецензії на прослухані ними лекції. Тут ми вже можемо зазначити, що їхні рецензії можуть бути показником впровадження інновацій на рівні університету.

У 2017 - 2018 навчальному році із заслуханих на практичних заняттях рецензій ми можемо зробити висновок, що більшість лекторів дотримуються класичного монологічного читання лекції, які не сприймається студентами як позитивний показник. Вони зазначають відсутність інноваційних активних підходів, які демонструють самі під час представлення власних розробок щодо проведення заняття тої чи іншої організаційної форми. Можемо 3 впевненістю зазначити, що такий підхід до організування і змістово-методичного наповнення практичних занять сприяє готовності майбутніх науково-педагогічних працівників до розроблення i впровадження інноваційних підходів в забезпеченні мети педагогічної діяльності у професійній освіті.

Цьогоріч ми запропонували аспірантам змоделювати особистість педагога-новатора сучасної вищої школи. Узагальнивши їхні підходи нам вдалось визначити, якого педагога чекає сучасна вища школа і яким педагогом готовий стати сучасний аспірант. Аспіранти виокремили такі основні риси педагога сучасної вищої школи, розмістивши за важливістю наступним чином:

1. Професіоналізм (фундаментальні і фахові знання, інтелектуальні, комунікативні здібності, професійна відповідальність).

2. Моральність, гуманність.
3. Володіння новітніми технологіями.

4. Здатність до самоменеджменту.

5. Особиста привабливість, почуття гумору, приємна зовнішність.

6. Володіння іноземною мовою.

7. Висока педагогічна техніка.

Дивним може здатись те, що педагогічна техніка поставлена на останнє місце, а ми це пояснюємо тим, що питання складових педагогічної майстерності не розглядались на лекціях і практичних, хоча зазначали про роль вербальної і невербальної комунікації, а тому маємо на меті ввести цей розділ у програму в наступному році. Це, на нашу думку, розширить індивідуальну траєкторію професійної підготовки майбутніх докторів філософії саме через педагогічну діяльність. Наш досвід організування роботи з майбутніми докторами філософії дає підстави виокремити деякі педагогічні умови підготовки їх до інноваційної педагогічної діяльності:

- застосування активних форм організування навчально-виховного процесу, які містять спеціально змодельовані навчально-професійні ситуації;

- запровадження курсів за вибором, що орієнтовані на інноваційну педагогічну діяльність;

- дотримання системного характеру формування готовності аспірантів до інноваційної педагогічної діяльності (як на рівні закладу, так і на рівні викладача).

Для успішного провадження інноваційної педагогічної діяльності в галузі власної спеціальності, науково-педагогічний працівник повинен відповідати ряду вимог. Спільно 3 кращими слухачами, які бачать себе педагогаминоваторами у майбутній вищій школі, ми намагаємось будувати модель сучасного науково-педагогічного працівника вищої школи, серед компонентів якої: професіоналізм, особистісні якості, досвід, потреба педагога бути новатором (проявляється у постійній роботі викладача над собою в контексті навчання протягом життя) тощо. Реалізуючи завдання формування готовності молодого педагога до інноваційної діяльності, зібраний нами матеріал схематичного представлення моделей педагогановатора за кожною спеціальністю планується представити у рамках “Конкурсу проектів моделі підготовки сучасного педагога-новатора “Львівської політехніки”.

Оскільки освітньо-наукові програми підготовки докторів філософії мають два взаємопов'язані рівні: якісна фахова підготовка та підготовка до інноваційної педагогічної діяльності, роботу з формування педагога-новатора серед аспірантів 

ДОІННОВАЦЙНОӤ ПЕДАГОГІЧНОЇ ДІЯЛЬНОСТІ

під час вивчення дисципліни “Професійна педагогіка" не вважаємо за самоціль. Складність i комплексність цієї проблеми зумовлює різнобічність наукових пошуків, розробки спеціальних методик реалізації їі завдань. На основі досвіду роботи з аспірантами можемо стверджувати, що готувати їх до інноваційної педагогічної діяльності можна лише через упровадження інноваційних методик формування компетентностей, які пов'язані зі здатністю науково-педагогічного працівника розробляти та реалізовувати новації.

Висновки та перспективи подальших досліджень. Проведений нами аналіз наукових джерел та власного досвіду засвідчує, що робота 3 формування готовності майбутніх докторів філософії до інноваційної педагогічної діяльності повинна спрямовуватись на формування у них таких компетентностей:

- здатність формувати інформаційний простір та реалізовувати його в процесі педагогічної взаємодії;

- здатність аналізувати та оцінювати педагогічні ситуації та розв’язувати педагогічні задачі;

- здатність застосовувати сформовані уміння і навички для здійснення педагогічної діяльності;

- здатність визначати цілі інноваційної педагогічної діяльності;

- здатність до об'єктивної самооцінки щодо впровадження інновацій упрофесійній педагогічній діяльності.

До подальших напрямів дослідження відносимо розробку моделі готовності майбутнього доктора філософії до педагогічної діяльності у сфері професійної освіти.

\section{ЛITEРАТУРА}

1. Агапова С.А. Индивидуальная траектория профессионального развития педагога / С.А. Агапова // Среднее профессиональное образование. - 2010. №2. - С.64-66.

2. Ангеловски К. Учителя и инновации: [кн. для учителя] / Крсте Ангеловски; пер.с макед. В.П. Диденко. - М.: Просвещение, 1991. - 159 с.

3. Бухнієва О.А. Підготовка аспірантів до інноваційної діяльності у вищому навчальному закладі: дис.канд. пед.наук: 13.00.04 / Олена Анатоліївна Бухнісва. - Одеса, 2011.-311 с.

4. Гавриш І.В. Формування готовності майбутніх учителів до інноваційної професійної діяльності (методологічний і теоретичний аспекти) / І.В.Гавриш. - Харків:ХОНМІБО, 2005.-388 с.

5. Гінсіровська І.Р. Підготовка майбутніх фахівців інженерно-технічного профілю до інноваційної діяльності як предмет науково-педагогічних досліджень / І.Р. Гінсіровська // Вісник Черкаського університету.
Серія : педагогічні науки. - Черкаси, 2014. - Випуск 40 (293). - C.24-29.

6. Кузьмін С.В. Инновационная деятельность педагогического коллектива как фактор его развития: дис.... канд.пед.наук : 13.00.01/ Сергей Владимирович Кузьмин. - Ярославль, 2003. - 197 с.

7. Пискарева И.Е. Формирование готовности будущих учителей к инновационной деятельности: дис...канд.пед.наук: 13.00.08 / Пискарева Инна Евгеньевна. - Косторома, 2000. - 150с.

8. Попова О.В. Інновації в сучасній педагогічній теорії та практиці. Педагогіка та психологія: Збірник наукових праць / За заг. Ред. Акад. І.Ф. Прокопенка, члкор. В.І. Лозової. - Харків:ХДПУУ, 1999. - Вип.9.-С.10-15.

\section{REFERENCES}

1. Agapova, S. A. (2010). Individualnaya traektoriya professionalnogo razvitiya pedagoga [[The individual trajectory of the professional development of teacher]. Secondary vocational education. No. 2, pp.64-66. [in Russian].

2. Anhelovski, K. (1991). Uchytelia y ynnovatsyy [Teachers and innovations]. The teacher's book. Moscov: Prosveshchenye, 159 p. [in Russian].

3. Bukhniieva, O. A. (2011). Pidhotovka aspirantiv do innovatsiinoi diialnosti u vyshchomu navchalnomu zakladi [The training of the postgraduate students to the innovative activities at higher educational institution]. Candidate's thesis. Odesa, 311 p. [in Ukrainian].

4. Havrysh, I. V. (2005). Formuvannia hotovnosti maibutnikh uchyteliv do innovatsiinoi profesiinoi diialnosti (metodolohichnyi i teoretychnyi aspekty) [The formation of the future teachers' readiness to the innovative professional activities (the methodological and theoretical aspects)]. Kharkiv: KhONMIBO, 388 p. [in Ukrainian].

5. Hinsirovska, I. R. (2014). Pidhotovka maibutnikh fakhivtsiv inzhenerno-tekhnichnoho profiliu do innovatsiinoi diialnosti yak predmet naukovo-pedahohichnykh doslidzhen [The preparation of the future specialists of the engineering and technical profile for innovation as a subject of the scientific and pedagogical research]. Bulletin of Cherkasy University. Series: pedagogical sciences. Cherkasy, Vol. 40 (293), pp.24-29. [in Ukrainian].

6. Kuzmin, S.V. (2003). Innovatsionnaya deyatelnost pedagogicheskogo kollektiva kak faktor ego razvitiya [The innovative activity of the pedagogical team as a factor in its development]. Candidate's thesis. Yaroslavl, 197 p. [in Russian].

7. Piskareva, I. Ye. (2000). Formirovanie gotovnosti budushchikh uchiteley $k$ innovatsionnoy deyatelnosti [The formation of readiness of future teachers to innovate activities]. Kostoroma, 150 p. [in Russian].

8. Popova, O.V. (1999). Innovatsii v suchasnii pedahohichnii teorii ta praktytsi. Pedahohika ta psykholohiia [The innovations in the modern pedagogical theory and practice. Pedagogy and Psychology]. The collection of scientific works. (Ed.).I. F. Prokopenko. Kharkiv: KhSPU, Vol.9, pp.10-15. [in Ukrainian].

Стаття надійшла до редакції 15.11.2018 